\title{
Pursuing an Elusive Quarry: The Battle of Cane Hill, Arkansas
}

\section{Authors: Kim Allen Scott \& Stephen Burgess}

"This is the final version of record of an article that originally appeared in Arkansas Historical Quarterly in March 1997."

Scott, Kim Allen, and Stephen Burgess. "Pursuing an Elusive Quarry: The Battle of Cane Hill, Arkansas." Arkansas Historical Quarterly 56, no. 1 (1997): 26-55.

Made available through Montana State University's ScholarWorks 


\title{
Pursuing an Elusive Quarry: The Battle of Cane Hill, Arkansas
}

\author{
KIM ALLEN SCOTT and STEPHEN BURGESS
}

\begin{abstract}
"I ATTACKED GENL. MARMADUKE at this place on the 28th inst ... and thrashed him out of his boots and britches." (Brig. Gen. James G. Blunt, USA) ${ }^{1}$

"We fought them all day with but slight loss and at dark we moved off with the federals pursuing. It was at Cane Hill. I suppose they will make a great to do over it, but I assure you they ought to hide their faces instead of boast." (Maj. Robert Henry Smith, CSA) ${ }^{2}$
\end{abstract}

The statements of General Blunt and Major Smith are prime examples of the researcher's dilemma when pursuing that most elusive quarry, historical truth. Both Blunt and Smith personally witnessed the battle of Cane Hill, Arkansas, yet each man saw the results of the clash in an entirely different manner. Their divergent conclusions on the fight confront us much like the stories a policeman gathers from witnesses to a traffic accident. Three people standing at an intersection can easily relate to an investigator three entirely

Kim Allen Scott is special collections librarian at Montana State University. Stephen Burgess is a former Fayetteville resident now living in Fredericksburg, Virginia. This article won the 1996 Arkansas Historical Association's Lucille Westbrook Award for Local History. The authors wish to thank Kevin Burgess for preparing the maps of the battle.

${ }^{1}$ James G. Blunt, telegram to Brig. Gen. John M. Schofield, November 18, 1872, John M. Schofield Papers, Manuscripts Division, Library of Congress.

${ }^{2}$ Robert Henry Smith to Susan Oliver Smith, November 30, 1862, Smith-Mendenhall Family Papers, Montana State University, Bozeman. 
different versions of how the cars collided, yet each story is dutifully recorded for presentation to the court for judgement.

But if history is a trial proceeding, should the hearing on the battle of Cane Hill be held in a civil or criminal court? In a civil proceeding we need merely to present a case based on a preponderance of the evidence, a task much easier than the criminal court requirement of proof beyond a reasonable doubt. This burden of proof is where the historian must part company with the traffic investigator, for while the latter may be able to reconcile the observations by three witnesses to fix liability for the accident, the historian is forced to admit that the surviving sources on Cane Hill are heavily skewed towards the side claiming victory in the battle. An additional challenge faces anyone who would attempt to unravel the conflicting testimony of this fight; the petty jealousies and political backbiting in which the principal characters indulged may or may not be typical of Civil War commanders, but their willingness to record their sniping alerts us to the possibility that their stories on Cane Hill may be colored accordingly. The historian, much like the traffic investigator, should rely not only on the witness depositions, but also examine the physical evidence remaining at the scene. ${ }^{3}$ The physical legacy of the desperate chase that occurred at Cane Hill on November 28, 1862, can help verify locations that are somewhat vague in the written accounts. The following narrative describing the battle is based on a critical evaluation of all of the aforementioned evidence but will verify that the truth of the matter is a most elusive quarry.

After the Confederate defeat at Pea Ridge, Arkansas, on March 7-8, 1862, Maj. Gen. Earl Van Dorn's combined southern forces moved to reinforce the Rebel armies in western Tennessee, virtually abandoning northwest Arkansas to Federal occupation. The victorious Federal army, however, marched off toward northeast Arkansas and the area around the town of Batesville. Union general Samuel Ryan Curtis hoped to capture the Mississippi River town of Helena, but the Arkansas secessionist government raised such a clamor in Richmond that a new southern general sped to the defense of the state.

\footnotetext{
${ }^{3}$ No archeological survey of an American Civil War site, whether amateur or professional, can provide a definitive picture of the events which occurred at the site, but speculative conclusions can be reached when unique ordnance known to have been used at a particular time is recovered. The metal detector surveys and excavations of the Cane Hill battlefield which will be cited in this paper were conducted on private property with the generous permission of several different landowners between 1987 and 1994.
} 
Maj. Gen. Thomas C. Hindman took command of the First Corps of the Confederacy's Trans-Mississippi army on August 24, 1862, quickly bringing to Confederate Arkansas an energy that had been sorely lacking. Using a mere skeleton force, Hindman started a campaign of deception that stalled the Union advance while he mobilized the rest of state. The new Rebel commander enforced the Confederate government's conscription act to the fullest extent and set up a network of supply factories to produce everything from shoes to gunpowder for the growing southern army. By midsummer of 1862 the Rebels had taken back northwest Arkansas and even moved again into southwest Missouri. ${ }^{4}$

As his conscript force grew, General Hindman replaced several subordinates with more able officers. Two of the new commanders were Brig. Gen. John Sappington Marmaduke, appointed to lead the southern cavalry division, and Col. Joseph Orville Shelby, chosen to head a brigade within Marmaduke's division. These two Missourians would be Hindman's choice to direct the movement towards Cane Hill and would prove themselves most worthy of the assignment.

Northern strategists in Missouri had not failed to notice the Confederate buildup. While two divisions of the Union Army of the Frontier tramped into the field from southeastern Missouri, a third advanced from eastern Kansas to join them. Brig. Gen. James G. Blunt, a former physician from Kansas and a seasoned veteran of the longtime border conflict, led the troops that formed the 1st Division of the Army of the Frontier, and although his commanding officer and many subordinates may have questioned Blunt's military judgement, they could not deny his aggressive willingness to engage the enemy whenever possible.

By late October Blunt had driven the Confederates out of Missouri, captured a four-gun battery at the battle of Fort Wayne in the Indian Territory, and positioned his division in southwestern Benton County, Arkansas, to observe any further Rebel incursions from the Arkansas River valley. So successful had Blunt's campaign been that Maj. Gen. John Schofield, the commander of the Army of the Frontier, recalled the 2nd and 3rd Divisions to quarters near Springfield, Missouri, leaving Blunt's victorious 1st Division

\footnotetext{
${ }^{4}$ David Yancey Thomas, Arkansas in War and Reconstruction (Little Rock: United Daughters of the Confederacy, 1926): 140-142; William L. Shea, "1862, 'A Continual Thunder"' in Rugged and Sublime: The Civil War in Arkansas, ed. Mark K. Christ (Fayetteville: University of Arkansas Press, 1994), 45-48.
} 
Kansans to manage by themselves in northwest Arkansas. Blunt continued to occupy his troops by scouting the territory south towards Hindman's gathering forces at Van Buren and by setting his men to the destruction of Rebel property. "It is very certain that this country will afford short living for a bushwhacker when I leave it," he wrote to General Schofield. ${ }^{5}$

Hindman acted quickly to take advantage both of Blunt's aggressiveness and of Schofield's complacency as winter approached. Hindman's plan of attack called for a large cavalry force to be sent from Van Buren in the Arkansas River valley across the Boston Mountains to Boonsboro ${ }^{6}$ and Newburg, two small towns in southwest Washington County situated along Jordan Creek and a broad ridge known as Cane Hill. Hindman's troops were to seize forage supplies in this rich agricultural area and draw the attention of Blunt's division. With the Yankees thus diverted by the threat of a major attack at Cane Hill, Hindman, with his main force, could march up the Cove Creek road from Van Buren and strike the enemy in the rear, defeating Blunt's army before any help could arrive from the other two divisions in southern Missouri.? $^{2}$

Blunt's division of the Army of the Frontier consisted of three brigades commanded by Brig. Gen. Frederick Solomon, Col. William Weer, and Col. William F. Cloud. Just as Blunt would later freely express his contempt for General Schofield in his memoirs, subordinate officers in the lst Division did not hesitate to criticize both Blunt and each other. Samuel J. Crawford, an ambitious politician then serving as a captain in the 2nd Kansas Cavalry, considered General Blunt to be slow-witted and publicly declared his order of march to Cane Hill to be "ill conceived, and his plan of battle . . worse." Crawford's own brigade commander, Col. William F. Cloud, had been dubbed "the pettiest creature out of petticoats" by Col. Thomas Ewing Jr. of the 11th Kansas Infantry. "If he had any brains I could stand him better but he has

\footnotetext{
${ }^{5}$ Blunt to Schofield in War of the Rebellion: A Compilation of the Official Records of the Union and Confederate Armies (Washington, DC: GPO, 1883) ser. 1, vol. 13, 786 (hereafter cited as $O R$, and all references are to series 1 ).

${ }^{6}$ Boonsboro was also spelled as Boonsborough.

${ }^{7}$ Ibid., vol. 22, pt. 1, 139. Hindman, after the battle of Prairie Grove, summarized his strategy in this report.

${ }^{8}$ Samuel J. Crawford, Kansas in the Sixties (Chicago: A.C. McClurg, 1911), 68.

${ }^{9}$ Thomas Ewing Jr. to Ellen Ewing, December 18, 1862. Thomas Ewing Family Papers, Box 68, Library of Congress.
} 
none. He is not fit to command more than a company."10 Col. Weer, in command of the second brigade, endured a firm reputation as a drunk among his colleagues ever after his temporary removal from command for insobriety on March 14, 1862."

Political considerations and personality tensions show up in some accounts left by enlisted men in the Army of the Frontier. For a newspaper back home, Pvt. G. E. Beates of the 2nd Kansas Cavalry prepared a letter that touted the bravery of Captain Crawford at Cane Hill to the detriment of his commanding officer, Lieutenant Colonel Bassett. Beates's animosity was due primarily to Bassett's military appointment by the state's previous governor. ${ }^{12}$ The stories of other Union enlisted men are peppered with descriptions of confiscation of Rebel property, revelations of tensions within the ranks, and a contemptuous dismissal of all things southern. Pvt. Robert T. McMahan, an educated trooper who manned the guns of Stockton's 25th Ohio Battery, kept a diary that detailed the brutal murder of one of the army's surgeons at camp and McMahan's own pilfering of books from libraries at Newtonia, Missouri, and Cane Hill College. Both activities resulted in officers assembling their units to discover the guilty parties. ${ }^{13}$ Pvt. John Howard Kitts of the 11 th Kansas Infantry shrugged off the protests of civilians he considered "rank secesh" in his own diary while boasting over the prowess of his comrades in destroying their property. ${ }^{14}$ This tendency of the Union soldiers to justify any activities of their own while dismissing any valor on the part of their enemies renders their testimony suspect and needful of careful examination.

The Confederate witnesses to the fight at Cane Hill are few in comparison to the Union sources, but external criticism clarifies their testimony as well. Animosity between Arkansas and Missouri Confederates had been the rule ever since the fall of 1861, when Brig. Gen. Benjamin McCulloch refused to

${ }^{10}$ Ewing to Ewing, November 25, 1862.

${ }^{11}$ OR, vol 13, 484.

${ }^{12}$ G. E. Beates to William S. Blakely, December 3, 1862, Josephine B. Martin Collection, Kansas State Historical Society, Topeka, Kansas.

${ }^{13}$ Robert T. McMahan, diary, November-December 1862, Robert T. McMahan Papers, Western Historical Manuscript Collection, University of Missouri-Columbia. For another incident which resulted in an assembly of troops in formation to identify malefactors, see: Kim Allen Scott, "The Preacher, the Lawyer, and the Spoils of War," Kansas History 13 (Winter 1990-1991): 206-217.

${ }^{14}$ John Howard Kitts, "The Civil War Diary of John Howard Kitts," Collections of the Kansas State Historical Society 14 (1915): 318-332. 
aid Maj. Gen. Sterling Price in his attempts to drive Union troops from Missouri. Statements on Cane Hill reflect this continuing grudge. General Shelby's after-action report also requires judicious examination because he allowed his adjutant, John N. Edwards, a former newspaper editor, to write the version that appears in War of the Rebellion; Official Records of the Union and Confederate Armies. ${ }^{15}$ In 1867 Edwards wrote his own reminiscences on Cane Hill with the same colorful hyperbole, allowing his imagination to further embellish the incidents that he had recorded so carelessly five years earlier. ${ }^{16}$ The timing of the southern Cane Hill accounts is also a factor to be considered. John M. Harrell and A. V. Rieff wrote their statements in 1899 and 1908 respectively, long enough after the event for Rieff to become confused concerning his regimental affiliation and commanding officer. ${ }^{17}$

As General Hindman gathered his forces near Van Buren at the beginning of November, he faced a very serious problem. The growing southern army desperately needed food, and as a result of the constant demand, the resources in the Arkansas River valley grew scant. Although the Cane Hill region lay dangerously close to Blunt's encampment, Hindman knew the area to be blessed with productive farms and working gristmills. He decided to dispatch Marmaduke's division to the area to secure sustenance and also to determine Blunt's strength at Lindsay's Prairie. Marmaduke's division consisted of Missouri cavalry brigades led by Shelby and by Col. Emmett MacDonald, along with a third brigade of Arkansas horsemen under the command of Col. William Carroll. All told, this force of mounted southern soldiers could not have numbered much more than two thousand men with six pieces of artillery. Marmaduke's force set out in the early days of November to the Cane Hill area, terrorizing the Unionist residents and treating Confederate sympathizers with nearly the same callousness as they demanded grain for the army in exchange for southern script. ${ }^{18}$

\footnotetext{
${ }^{15} \mathrm{OR}$, vol. 22, pt. 1, 55-58. Not only is the prose style Edwards's alone, this report is one of the few in the Official Records which includes quotes from Scottish poetry.

${ }^{16} \mathrm{John}$ N. Edwards, Shelby and his Men, or, The War in the West (Cincinnati: Miami Printing and Publishing, 1867), 93-104.

${ }^{17} \mathrm{John}$ M. Harrell, Confederate Military History (Atlanta: Confederate Publishing, 1899), 136-145; A. V. Reiff, statement on Cane Hill, March 6, 1908, Charles E. Cory Papers, Kansas State Historical Society.

${ }^{18}$ Amanda Braly to William Carrick Braly, November 15, 1862, Amanda Malvina Fitzallen McClellan Braly Family Papers, 1841-1920, Special Collections, University of Arkansas Libraries, Fayetteville; Walter J. Lemke, ed., The Hermanns of Old Hermannsburg
} 


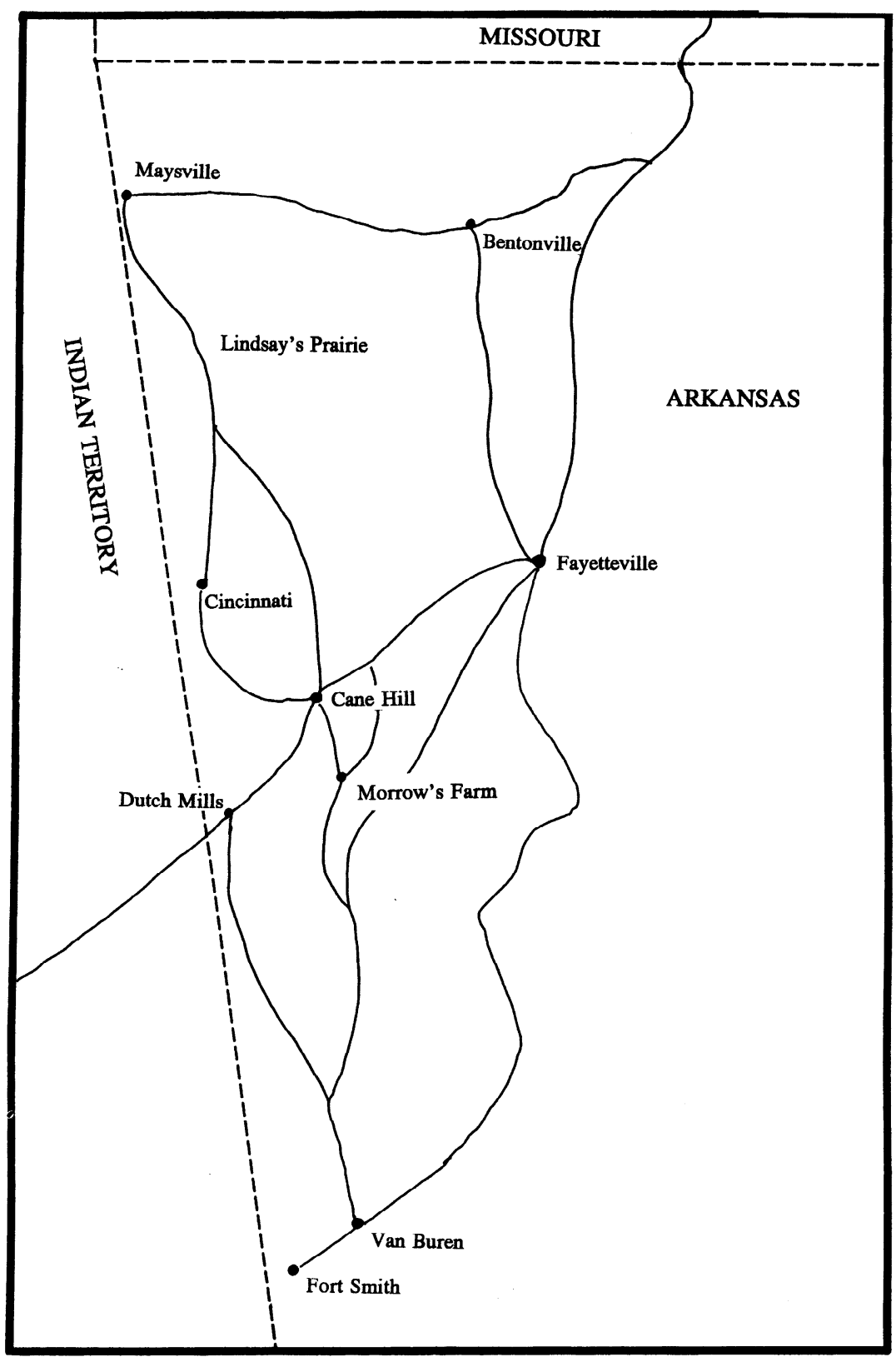


While they were confiscating the products of gristmills at Cane Hill, Rhea's Mill, and Hermansburg, Marmaduke's troops encountered scouting parties sent by Blunt to trace their movements. One of the first clashes came on November 8 along the road from Fayetteville to Cane Hill near William Graham's house at Boonsboro. There Federal cavalry under the command of Colonel Cloud exchanged shots with Rebels. Amanda Braly, a resident of Newburg, a town two miles south of Boonsboro, reported in a letter to her son that she had heard the encounter was bloodless. ${ }^{19}$ Blunt's official synopsis of the action describes what almost appears to be a dress rehearsal of the coming battle at Cane Hill, with Federal cavalry chasing Emmett MacDonald's horsemen down the Cove Creek road to within eighteen miles of Van Buren, capturing a battle flag, and destroying the Rebel supply train. ${ }^{20}$

If Braly and the other southern sympathizers at Newburg expressed relief when Marmaduke's soldiers returned to their town on November 10, their celebration proved premature. Again, Marmaduke's quartermaster, Maj. Robert Henry Smith, ordered his soldiers into the surrounding countryside to forage for grain from citizens regardless of their allegiance. "I must confess that it is working me harder that I would like," he wrote to his wife about his assignment, "as many are the nights that I do not sleep an hour." detachment arrived at the small German settlement at Hermansburg (present day Dutch Mills), five miles to the west of Newburg, where they worked the mill owned by Nani Herman through the day of November $13 .{ }^{22}$ The following morning a motley assortment of Union-allied "Pin" Indians attacked this group and sent them flying back to Marmaduke's headquarters at Kidd's Mill, halfway between Boonsboro and Newburg. Another patrol from Blunt's army arrived at Cane Hill the same day, but Susan McClellan, an area civilian, warned Shelby's camp of the approaching menace in time for the Missourians to prepare an ambuscade. Only southern viewpoints are represented in the

(Fayetteville: Washington County Historical Society, 1965), 49. Both of these sources mention grain confiscation by Confederate forces.

${ }^{19}$ Braly to Braly.

${ }^{20}$ OR, vol. 13, 358; Crawford, Kansas in the Sixties: 62-63. Captain Crawford, who accompanied the 2nd Kansas Cavalry in this fight, painted a colorful word picture of the affair but avoided the mention of casualties.

${ }^{21}$ Smith to Smith, November 30, 1862, Smith-Mendenhall Papers.

${ }^{22}$ Lemke, The Hermanns of Old Hermannsburg, 49. 
reports on this affair, but even these accounts vary. ${ }^{23}$ The bloodcurdling prose of Major Edwards contrasted with Braly's matter-of-fact report:

When within point-blank range, the snaky fence, lit up by the flash of 3,000 muskets, revealed a line of sullen men pouring death into the shattered [Federal] ranks, while [Capt. Hiram] Bledsoe's four-gun battery hurled an iron tempest into their very faces. ${ }^{24}$

Yesterday morning about sunrise a company of feds came into Boonsboro and figured around, and I heard they took some horses. Our men fired on them with small arms, and Bledsoe's battery, but they got away. Report says they killed four but I doubt it....It is now the middle of the evening and word has come that the feds are at the Burg. They no doubt have friends here that lets them know the movements of our army. ${ }^{25}$

The constant Confederate raiding of gristmills and the periodic encounters with Union scouts sent to watch them resulted in an overabundance of intelligence on the part of both armies. As Braly indicated in her letter, both southern and northern sympathizers lived around Cane Hill, and they assisted the armies of their choice when the opportunity arose. Both sides kept a close eye on one another, perhaps too close for the Union army. After a scout returned on November 23, General Blunt became convinced that the Confederates had over eight thousand men at Cane Hill. Blunt had already tried unsuccessfully on November 15 to call to Schofield for reinforcements and later reported that, much to his disgust, he learned of Schofield's abandonment of the 1st Division by reading a newspaper article in the St.

\footnotetext{
${ }^{23}$ This skirmish is not described in the Official Records nor is it listed in Dyer's Compendium, but the evidence is clear that the incident did take place. Aside from Edwards's and Braly's accounts, Shelby himself reported the fight in a glowing recommendation of Lieutenant Bledsoe forwarded to Marmaduke, stating that the artillery officer's courage that day "should be emulated by others." J. O. Shelby to J. S. Marmaduke, November 26, 1862. Correspondence of J. S. Marmaduke, 1863-1864, Record Group 109, National Archives, Washington, DC.

${ }^{24}$ Edwards, Shelby and his Men, 97.

${ }^{25}$ Braly to Braly, November 15,1862 , Braly Family Papers.
} 
Louis Democrat ${ }^{26}$ Tired of the successful manner in which Hindman's army constantly replenished their stores at Cane Hill and convinced that his isolated division's best chance lay in offensive action, Blunt made ponderous arrangements to drive the enemy permanently out of the area and thus open the way to Fort Smith.

On November 27, 1862, Blunt began his move south. He left the Benton County camp at Lindsay's Prairie in the early morning with five thousand troops and thirty pieces of artillery from all three of his brigades, leaving behind a small force to guard the supply train. As it turned out, the nature of the terrain and the necessity to march his troops in a narrow column limited the participation in the coming battle to a small portion of the advance. Ordering the men to carry four-days' rations, Blunt proceeded with his force down the road to Cincinnati, a small town on the border of the Indian Territory. Thirtyfive miles separated Lindsay's Prairie from Cane Hill, and Blunt's army managed to cover twenty-five of them before stopping for the night of November 27 on an elevation to the northwest of Rhea's Mill. At five o'clock the next morning, Blunt's army was again on the march, reaching Rhea's Mill by sunup and then leaving the main road to proceed directly south to the enemy.

The Union army had their choice of three routes to the small Jordan Creek valley below Cane Hill. One road entered the valley from the west, the direction from Cincinnati and the Indian Territory. This road led directly in front of the cemetery for the town of Boonsboro before joining the main road that paralleled the creek. This main road, running generally southwest from Fayetteville, linked the towns of Boonsboro and Newburg and then forked, with the western leg leading to Hermansburg and the eastern leg pointing to a junction with Cove Creek road about five miles beyond. A shortcut trail from Rhea's Mill to Cane Hill joined the Fayetteville-Boonsboro route about a half mile north of the junction with the road to Cincinnati. Little used due to its path along steep ridges, this shortcut proved to be the perfect choice for Blunt's final approach to Cane Hill.

\footnotetext{
${ }^{26} \mathrm{OR}$, vol 13, 795; James G. Blunt, "General Blunt's Account of his Civil War Experiences," Kansas Historical Quarterly 1 (1931): 229.
} 
Although he left no written report on his actions at Cane Hill, it is obvious that Marmaduke fully expected an attack that day. ${ }^{27}$ The southern general had already started his supply train down the road to the Cove Creek junction in order to send the confiscated flour and grain over the mountains to Van Buren, just as he had previously done several times that month. To use Edwards's words, the cavalry division had "stripped to the waist" for fighting after accomplishing their primary objective, that of again seizing badly needed supplies. ${ }^{28}$ We can only use later testimony to surmise that a second objective existed for Marmaduke's command that day - to lure Blunt to Cane Hill while the rest of Hindman's army in Van Buren proceeded north on the Cove Creek road to strike the Yankee force in the rear. This second objective seems arguable in that Hindman would not be ready to move for another week, and Marmaduke had no way of knowing in advance that Blunt would stop his army's forward thrust short of the Cove Creek road. ${ }^{29}$

The regiments of Colonel Shelby's brigade held the northernmost portion of the Rebel's Cane Hill encampment. At the Boonsboro cemetery, which was located at the northeast corner of section 8, Township 14 north, Range 32 west, Shelby positioned one of Bledsoe's six-pound howitzers in his command to guard the approach from the Fayetteville road. The other gun had been planted several dozen yards to the west along the road leading to Cincinnati where the ridge of Cane Hill leveled before descending again to the west. Since spies reported that Blunt had passed Cincinnati the previous night, Shelby fully expected the attack to come from that direction, but the Rebel colonel had sent patrols out along the Fayetteville road as well just to make sure. One

\footnotetext{
${ }^{27}$ Marmaduke wrote no after action report on the battle of Cane Hill for the simple reason that he did not have enough paper and ink with which to prepare one. However, he did confirm in a letter sent to General Hindman the morning of the fight that he expected the enemy at any moment from the Cincinnati or Fayetteville roads. J. S. Marmaduke to T. C. Hindman, November 28, 1862, November 29, 1862, P. W. Alexander Papers, Special Collections, Columbia University Libraries.

${ }^{28}$ Edwards, Shelby and his Men, 98.

${ }^{29}$ Marmaduke did approach Hindman with a plan very similar to the one we have speculated existed on November 28 . In a very revealing letter written on November 24, Marmaduke proposed that Hindman use the circuitous route to attack Blunt's camp at Lindsay's Prairie. At that time Marmaduke suggested his cavalry could act as a screening force to intercept anyone travelling north from Fort Smith to warn Blunt of the impending attack from the rear. Marmaduke to Hindman, November 24, 1862.
} 


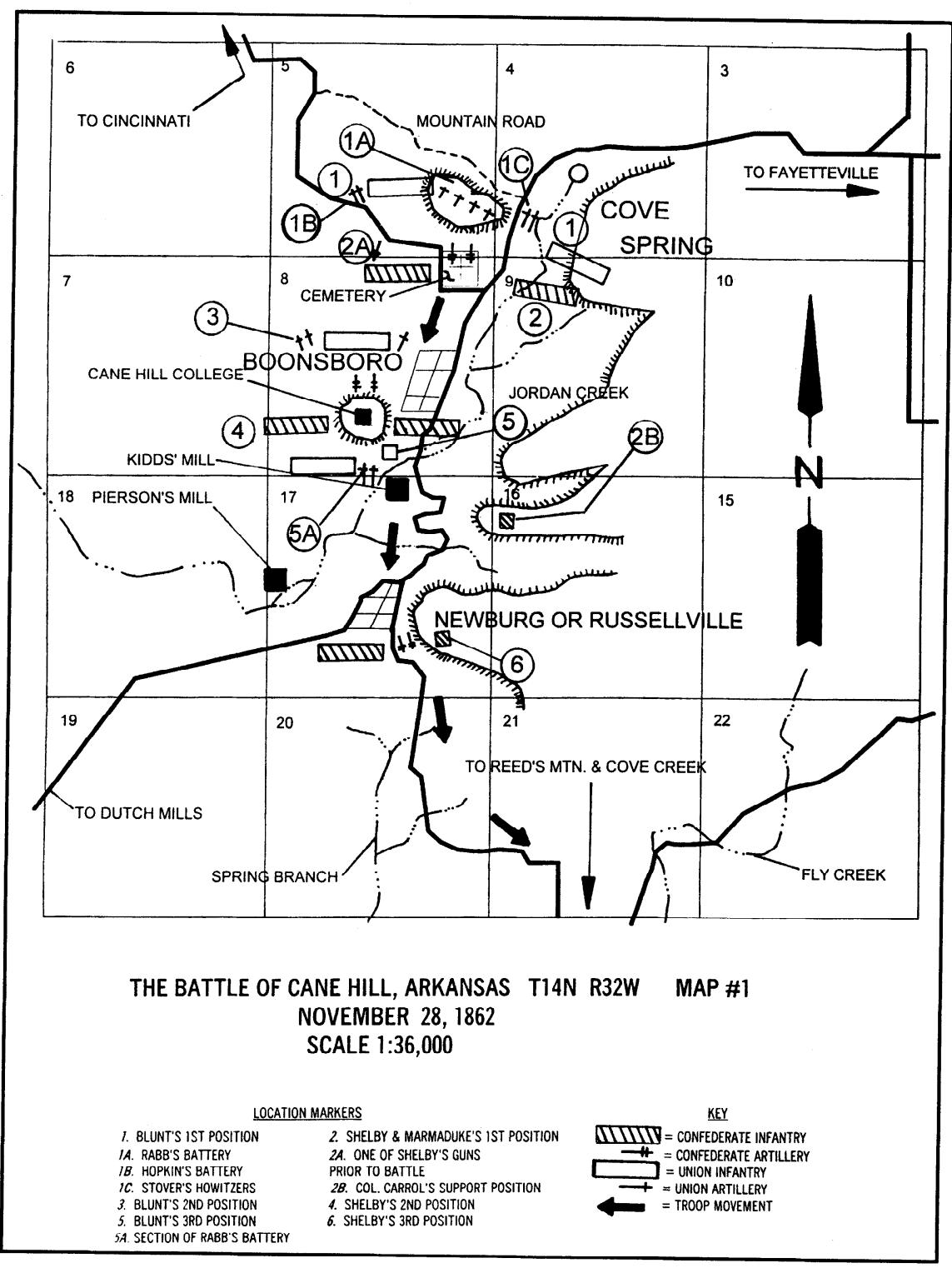


group of these scouts lingered near the intersection of the Rhea's Mill shortcut as the morning of November 28 dawned.

Meanwhile, Blunt's army stumbled the remaining ten miles to Cane Hill over the little-used road leading south from Rhea's Mill. The general, with his bodyguard and personal staff, led the procession for a while, but as they neared the town he sent ahead companies C, I, and G of the 2nd Kansas Cavalry, under the command of Maj. James G. Fisk, to locate the Rebel pickets. Lt. E. S. Stover accompanied this advance with a battery of mountain howitzers, while Lt. John W. Rabb's 2nd Indiana Battery remained behind with Blunt. Miles behind this advance force the rest of the Yankees followed, their pace regulated by the 11th Kansas Infantry. Major Fisk's troopers passed down the Rhea's Mill road to the intersection with the Fayetteville road and, seeing Shelby's patrol ahead, immediately opened fire. The surprised Confederate scouts responded with a few shots, and when Colonel Cloud arrived on the scene to direct Stover's howitzers into position, the scouts fled down the main road to rejoin Shelby's line at the cemetery. Fisk's troopers gave chase, but after they had passed the steep gorge which led to the opening of the Jordan Creek valley, they halted. They were looking straight up into the muzzle of Bledsoe's battery on the cemetery hill.

Again the accounts differ as to who fired the opening shots. Colonel Cloud claimed that the southerners were completely surprised when one of Stover's mountain howitzers lobbed a cannon ball into Shelby's camp. ${ }^{30}$ Shelby's adjutant, Edwards, said that his side supplied the surprise: "Collins [Shelby's artillery officer] opened first and shot a great gap in the leading regiment. . . a fresh discharge scattered the regiment like chaff to the shelter of the woods beyond."'31

He goes on to say that Blunt had to personally rally the advance troopers to keep them from running away. It is likely that Edwards is the witness to believe, since Blunt arrived with his bodyguard and staff just in time to see for himself the destructive expertise of Shelby's gunners. Stover moved his mountain howitzers to the right, trying to gain some elevation to answer the Rebel barrage, and as Major Fisk directed the placement of the guns, a shell burst over his head and removed a large piece of his scalp. Lieutenant Rabb and his heavier guns also tried to gain some elevation to the right but fared no

${ }^{30} \mathrm{OR}$, vol. 22 , pt. $1,47$.

${ }^{31}$ Edwards, Shelby and his Men, 99. 
better. A well-aimed shot passed directly through one of the Indiana artillerymen and went on to drop two horses. ${ }^{32}$

By the time the Union batteries could effectively return fire, General Blunt saw that the sloping hillside to the right held the key to a successful flanking maneuver, but when he prepared to dispatch a force to reconnoitre, he realized that the main body of his army still struggled along several miles back along the Rhea's Mill road. Blunt, with a puny contingent of less than 250 men, faced the entire Confederate force, an army he believed numbered about 8,000. The general urgently sent Major Van Antwerp, his adjutant, galloping back to bring up more help at the double-quick. In the meantime all Blunt could do was deploy the dismounted troopers of the 2nd Kansas as support for his batteries and hope that the Rebels would not try a dash forward to take his guns. ${ }^{33}$

Shelby's men enjoyed a good position on the cemetery hill. Once his scouts returned with the welcome news that no enemy troops could be seen approaching from Cincinnati, Shelby ordered his second gun forward to continue the artillery duel. Cautiously eyeing the main road leading south to Boonsboro, the Rebel commander knew that he had to discourage any advance on the Union left that would deprive him of an escape route. By concentrating his dismounted troopers to protect the artillery, Shelby helped strengthen his right flank while simultaneously weakening his left, the Cincinnati approach ${ }^{34}$ This is exactly where Blunt wished to strike but lacked the troops to make the move. Once it became obvious the Yankees would make no immediate push on either side, the southerners contented themselves by shelling the enemy without making any forward movement.

Two miles back along the Rhea's Mill road, the 11th Kansas Infantry struggled along a steep and muddy mountain road. Behind the hard-slogging infantrymen followed the rest of the column--the remaining companies of the 2nd Kansas Cavalry, the battery of light guns captured at Fort Wayne and

${ }^{32}$ Theodore Gardiner, "The First Kansas Battery: An historical sketch, with personal reminiscences of army life, 1861-65," Collections of the Kansas State Historical Society, 1915-1918 14 (1918): 274. Although Gardiner was not an eyewitness to this opening fire, T. O. Adkins, a gunner in Rabb's battery, confirmed that two men and five horses were killed during the course of the battle. See T. O. Adkins, letter to Chambers Baird, December 1862. Chambers Baird Papers, Special Collections;, Duke University Library.

${ }^{33} \mathrm{OR}$, vol. 22, pt. 1, 44.

${ }^{34}$ Ibid., 56. 
commanded by Lt. Henry Hopkins, Tenney's lst Kansas Battery of heavy Parrot rifles, the 1st and 3rd Indian Home Guard infantry regiments, the 6th Kansas Cavalry, and the balance of Weer's brigade. The road became so steep in some places that the infantrymen had to help pull the guns along by hand, and after marching four hours from the camp near Rhea's Mill, most of the soldiers were simply worn out. The entire column paused at nine o'clock to close up when the booming of artillery could be heard in the distance ahead. Although Colonel Cloud later complained that the halt was made without orders and cost him an opportunity to capture the enemy guns, the reality of the marching conditions probably demanded a pause to close up the straggling Union column. ${ }^{35}$ Once he heard the cannons ahead, Captain Crawford, at the head of the 2nd Kansas A Company, became very agitated and urged his superiors to order the column forward at once. Col. Owen Bassett and Col. Thomas Ewing Jr. refused until Major Van Antwerp reigned in his lathered horse in front of the officers and explained the desperate situation ahead. ${ }^{36}$ Could the column be urged forward at the double-quick? It was no small request of men who had been hauling eleven-pound muskets and heavy packs up and down hills all morning, but once Bassett ordered his horsemen into files to pass the infantry on either side of the road, Ewing suddenly felt real fear-not the fear of an approaching rendezvous with death, but an apprehension that his command would again miss all of the action just as they had at Fort Wayne the previous month, when the cavalry had dashed ahead of Ewing's men to rout a small Rebel force before the infantry could arrive to participate. Colonel Ewing turned and ordered his men to drop their packs by the side of the road, and with their muskets at right shoulder shift, he led them forward at the double quick in the wake of the galloping troopers. Many of the men in the 11th had already straggled, and the grueling pace proved a severe trial for Capt. Edmund Ross and Capt. Henry Palmer, both of whom were in

${ }^{35}$ Ibid., 47.

${ }^{36}$ Crawford, Kansas in the Sixties, 69. 
ill health ${ }^{37}$ but through sheer force of will the regiment covered the ground at an astonishing rate. ${ }^{38}$

As the artillery duel raged, General Blunt nervously awaited his infantry. At least one thousand southern troopers under Shelby faced him on top of Cemetery Hill, and MacDonald had moved his own forces up behind Cane Hill College about a half mile further south for support. On the east side of Jordan Creek, opposite Kidd's Mill, Colonel Carroll's Arkansas cavalry had deployed on the top of a hill that ended in a steep bluff facing north towards Boonsboro. The gentle slope from the southern approach to this point allowed Carroll to position the cannon in his command near the summit, overlooking the road leading south from the town. Had Marmaduke ordered a general advance at this point, Blunt's scantily protected artillery could have easily been overrun, a possibility not lost on the Union commander. After what must have seemed an eternity, the remaining companies of the 2 nd Kansas arrived, dismounted, and fanned out towards the extended line to the west.

Rabb's battery worked to find the range of Bledsoe's guns and accurately planted a few James shells right in their midst. ${ }^{39}$ Shelby began ordering the gun's withdrawal as he noted more Union reinforcements pouring into the valley from the road north. He also ordered his men to remount and prepared to give ground on the road below in face of Rabb's newly won freedom to blast the way open while MacDonald's men waited to cover the retreat of their comrades back near the college.

${ }^{37}$ Henry E. Palmer, "An Outing in Arkansas, or Forty Days and a Week in the Wilderness," Civil War. Sketches and Incidents: Papers Read by Companions of the Commandery of the State of Nebraska, Military Order of the Loyal Legion of the United States 1 (1902): 213-225; Edmund G. Ross to Ellen Ross, November 30, 1862, Edmund G. Ross correspondence, Kansas State Historical Society.

${ }^{38}$ Noble L. Prentis, Kansas Miscellanies (Topeka: Kansas Publishing, 1889), 33. This source quotes an eyewitness to the regiment's rapid march to Prairie Grove on December 7, 1862 , at a pace that outmatched the cavalry.

${ }^{39}$ Rabb's Battery used projectiles called James Shells, and the resulting physical evidence is like a fingerprint because Rabb was the only crew using them that day. The shells had a tendency to occasionally land without detonating: if the projectile began to tumble in flight, it would not land nose first and therefore would remain intact. Even when these shells explode, they still leave telltale fragments from the iron rifling "wiffles" at the base. A fully intact shell and many fragments were located near the Cane Hill Cemetery, firmly establishing that position for Shelby's battery. For an in-depth study on the artifacts recovered at Cane Hill, see Stephen Burgess, "Battle of Cane Hill," Treasure Search/Found, 18 (March 1990): 44-52. 
Colonel Ewing brought his exhausted command forward and ordered Maj. Preston Plumb to lead five companies of the left wing into deployment near Rabb's guns. The right wing, consisting of companies A, F, D, I and C, went up the slope to the right to extend the line west of Stover's howitzers. Captain Ross quickly forgot about his rheumatoid knees as he led Company $\mathrm{E}$ in file to their position, fronted the men, and ordered them to lie down as the last shots from Bledsoe's battery exploded near Rabb's guns. Because Sgt. Sherman Bodwell's captain led Company $\mathrm{H}$ along a circuitous route to join the right wing companies further up the hill, Bodwell and his comrades had to exert even more effort to bring their company on line.$^{40}$ When all had arrived at their positions, Blunt ordered an advance and the men dashed forward with a roar. Small arms cracked from Shelby's troopers in a defiant final gesture, one dropping Plumb's horse from beneath him, ${ }^{41}$ but the soldiers of the 2nd and 11th Regiments sensed their adversaries' unwillingness to engage at close quarters and quickly took the high ground beyond the cemetery. From here they could see Weer's brigade pushing south along the main road to their left, led by the Indian infantry regiments. Ahead the second line of Rebels mounted under MacDonald's orders as Shelby's men poured past them and through Boonsboro to gain the escape south offered by the main road. General Blunt dispatched Hopkins's battery to his forces on the hill, and they all pressed forward as MacDonald's own troops also began to withdraw southeast towards Kidd's Mill. Once the Kansas soldiers had reached this point, they were checked by an unpleasant surprise: Carroll's battery on the ridge to the east of Jordan Creek opened up with just enough accuracy to stall the Yankees for a moment. ${ }^{42}$

Colonel Cloud, who ordered the 2nd Kansas to remount and pass down to the recently cleared roadbed, saw Carroll's command ahead covering the blockade with their cannon on the ridge to the left. Steep bluffs which terminated the hills on the east side of the creek prevented the Yankees from sending Rabb's guns up to deal with the Rebel menace and severely impeded efforts of the Indian infantry to flank their adversaries. Consequently, Clouds'

\footnotetext{
${ }^{40}$ Sherman Bodwell, diary entry, November 28, 1862, Sherman Bodwell Diary, Kansas State Historical Society.

${ }^{41}$ William E. Connelley, The Life of Preston B. Plumb (Chicago: Browne, Howell , 1913), $113 n$.

${ }^{42} O R$, vol. 22 , pt. 1,51 .
} 
men could only approach along the main road, an extremely hazardous route at best. ${ }^{43}$

Lieutenant Hopkins had four small guns at his command, and his men, all former cavalry troopers, were fairly new at their operation. But as Carroll's battery betrayed its position east of the creek, Hopkins managed to aim his guns directly at the Rebel cannon. Once Hopkins got the range, Carroll ordered the guns withdrawn down the south facing slope to the roadbed below to join in the general retreat. One of the guns broke its carriage in the race downhill, and the Rebels had to improvise a rope-sling to carry the tube while the shells from their enemy burst all around them. Hopkins's men ceased fire and, in company with right wing of the 11 th Kansas, made their way down the slope of Cane Hill to rejoin the road between the town and Kidd's Mill. ${ }^{44} \mathrm{He}$ had no further opportunity to deploy the pieces, and all contented themselves with continuing the chase.

Marmaduke ordered Carroll to take his command on down the road to Cove Creek, passing through Newburg with no further delay. Shelby and MacDonald, who had rallied on a ridge adjacent to Newburg that ran east and west, paused to cover Carroll's flight. The 11th Kansas reunited on the road below Kidd's Mills and prepared to move forward again, even though by now they had seemingly been pushed to the limit. "My regiment was nearly run to death," Colonel Ewing complained to his wife later, "and yet Cloud complained of them for not outracing the cavalry which kept the road during the fight while we struggled through the bush for 10 miles-THE PUPPY!"45

General Blunt had little time for faulting his frontline troops for their tardiness. He could see that Marmaduke had chosen a very good place beyond Newburg for defense and planned again to send his infantry on a flanking maneuver to dislodge them: "Having now concentrated their entire force, and selected this strong position, I felt assured they had resolved on a desperate resistance and made arrangements accordingly."

Blunt's arrangements demonstrated his conviction the Rebels would stand and fight. His orders included deploying the exhausted infantry far to the right and left of the roadbed, positioning Rabb's battery in the center to help dislodge the enemy, and hastening forward troops from Weer's brigade who

\footnotetext{
${ }^{43}$ Ibid., 47.

${ }^{44}$ Ibid., 52-53.

${ }^{45}$ Ewing to Ewing, December 2, 1862, Ewing Family papers.

${ }^{46} \mathrm{OR}$, vol. 22, pt. 1, 44.
} 
were steadily streaming into the Jordan Creek valley from the point where the fighting had begun. The 6th Kansas Cavalry managed to come up to the sight of the action, and the heavy Parrot rifles of Tenney's battery were set up on the road south of Kidd's Mills to assist in the fight. From the ridge Bledsoe's battery and Carroll's howitzers again barked defiance to the foe, but only long enough to cause the Federals to pause for the flanking maneuver. Once the Union forces spread out to begin the attack, Marmaduke ordered the retreat to begin anew and the southern soldiers suddenly abandoned the ridge. Tenney's battery managed to fire a few Parrot shells at the enemy before they completely disappeared ${ }^{47}$ and General Blunt recalled his flanking troops to the roadbed to resume the chase.

Casualties at this point in the fight had been extremely low. In the initial contact, the artillery duel near the cemetery, only two Union losses can be verified: Major Fisk, whose head wound proved serious enough to return him to Kansas, and the Indiana gunner serving under Captain Rabb. There are several reasons why so few men were killed or wounded. First, all of the small arms used in the engagement were of very limited range. The Union cavalry may have borne rifled carbines, but most of the southerners carried only shotguns and pistols. The 11th Kansas Infantry used huge .72 calibre smoothbore muskets that produced tremendous noise and smoke, but sent the buck and ball loads only a couple hundred yards with any killing force. An additional reason for the scant casualties is that considerably fewer than the total number of soldiers present at any given time were actually engaged. Dismounting cavalry required one-quarter of the force to hold the horses, and the infantry had less than a full contingent due to straggling. The nature of the terrain also helped reduce the number of killed and wounded. Thick brush, steep ravines, and the houses of Boonsboro and Newburg interfered with the fire of both sides. Finally, the tactics embraced by General Marmaduke were calculated to delay, rather than stop, the Union advance. The southerners made no offensive movements whatsoever during the first three hours of the battle and willingly retreated at the first show of the Union troops' determination to attack.

As Marmaduke's command flew down the road to Cove Creek, General Blunt again urged his army forward at the double-quick, even though the deployment and recall of the infantry required the exhausted soldiers to cover

\footnotetext{
${ }^{47}$ Gardiner, "First Kansas Battery," 247.
} 
the same ground twice at a run. Even the horses began to play out at this point; some dropped in their harness and had to be cut free in order to move the guns forward. ${ }^{48}$

When it became Shelby's turn to face the enemy and cover for Carroll's and MacDonald's fleeing columns, he performed a brilliant tactic that showed what a careful student of the school of war he had become. He arranged the individual companies of his brigade on either side of the road just beyond Newburg. When the last company in line fired their guns, they ran pell-mell up the road between the others until they passed to the front. Setting up a new position behind the first company, they could take their time to select the best cover and reload their weapons before the other units repeated the mancuver. Because of the successful execution of this tactic, the Union troops always faced a rank of loaded muskets during the chase. ${ }^{49}$

Colonel Carroll and his Arkansas cavalry had participated in little of the fighting up to this point. They first briefly halted with the rest of Marmaduke's army at the ridge near Newburg, but the general ordered Carroll to take his men down the road to Cove Creek along with his crippled guns. Obeying orders, Carroll did not stop until almost within a mile of John Morrow's house at the Cove Creek road intersection when, receiving further instructions to countermarch, he retraced his steps to place his last serviceable howitzer on the road at its highest point before it descended to Morrow's place. ${ }^{50}$ West of this position, the direction from which the retreat came, a small mound commanded the roadbed below and made an ideal spot for another delaying stand.

Marmaduke's decision to finally stand and fight at this point can be seen as circumstantial evidence that the southern strategy that day included keeping the Cove Creek roadway open after luring the northern army to Cane Hill. With the supply train of the last gristmill raid already sent safely back to Van Buren, the only objective remaining to Marmaduke, other than the preservation of his command, was to screen the hoped-for advance by Hindman, enabling him to strike Blunt in the rear. The general ordered Shelby's men to gather at the small mound, some dismounting at the top while the others spread out on

\footnotetext{
${ }^{48}$ Frank More, ed., The Rebellion Record: A Diary of American Events, with Documents, Narratives, Illustrative Incidents, Poetry, Etc. (New York: E. P. Putnam, 1863), 184. This source contains an anonymous Chicago Evening Journal reporter's version of the battle.

${ }^{49}$ Edwards, Shelby and His Men, 100.

${ }^{\text {so }} \mathrm{OR}$, vol. 22, pt. 1,54 :
} 


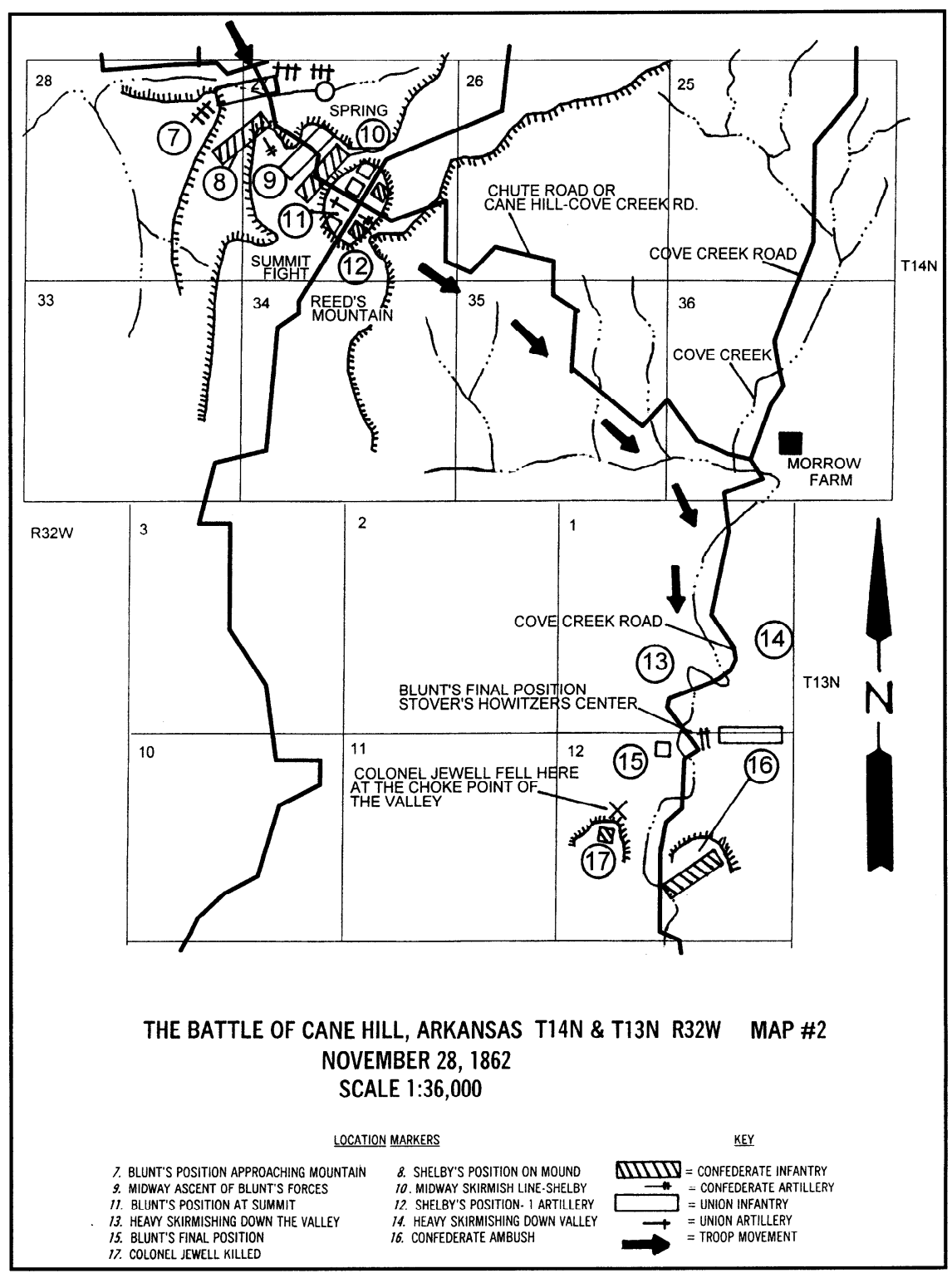


their horses below. One of Bledsoe's guns frowned at the roadbed from the mound's summit, prepared to receive the relentless Union advance.

A cornfield lay before the hill, and as troopers from the 2nd Kansas broke though the timber on the west side of the clearing, Shelby's men unleashed a volley from their shotguns and charged. A sharp exchange of gunfire followed before the Missourians quickly scrambled back up to the protection of Bledsoe's six-pounder and joined the dismounted supporting force. Colonel Bassett recalled his men to the timber in response to Bledsoe's deadly broadsides and waited for the Federal artillery to arrive. ${ }^{51}$ One of Stover's guns, commanded by Lieutenant Opdyke, pulled up, and Bassett sent him to the right of the road to a position where he could safely get closer to the Rebels. Rabb's guns arrived next and unlimbered in the middle of the road. ${ }^{52}$

Shelby peered down at his enemy's preparations, while one of his own officers planted a battleflag in the midst of their defensive line. Edwards recalled a moment of high drama in which the sun, previously obscured by a heavy cloud cover, suddenly burst through an opening in the overcast sky directly above Shelby's little contingent. "It is the sun of Austerlitz!" Shelby cried to his men with an inspired pose, although one naturally wonders how many of the Missouri horsemen would have grasped the Napoleonic metaphor at that crowded moment. ${ }^{53}$ The ammunition for Bledsoe's cannon finally gave out, and Shelby sent it back up to the top to the mountain to join the rest of the retiring guns. Now the fire from Rabb's and Stover's artillery became very hot, and the incessant crack of small arms added to the menace. In rapid succession, Shelby's horse was shot from under him, the black ostrich plume in his hat was clipped away by a bullet, and gore from the officer standing next to him spattered his face when that officer received a fatal bullet to the head. ${ }^{54}$ The Missouri horsemen, having successfully covered the retreat of Bledsoe's gun, withdrew to the main line of defense at the top of the mountain just as Captain Crawford led the 2nd Kansas to capture the top of the small hill they had vacated.

Blunt's army, like an accordion, stretched and compacted at several points along the five miles of road from where the battle had begun. Incredibly, Sergeant Bodwell and $\mathrm{H}$ company of the 11 th Kansas Infantry managed to

\footnotetext{
${ }^{51}$ Ibid., 50.

${ }^{52}$ Ibid., 44.

${ }^{53}$ Edwards, Shelby and His Men, 100.

${ }^{54}$ Ibid., 101.
} 
keep right up with the vanguard, although the 3rd Indian Home Guard had pushed ahead of them just before reaching the cornfield. As the cannon roared and the Indians shouted, Bodwell and his comrades approached the hilly ground:

Cannonading again in front. Rabb firing from a cornfield upon a very high wooded hill upon which the enemy made a stand. Heard the first musketry as we came up ... Filed right, up the steep hillside .. . Pass one of the K2d [2nd Kansas Cavalry] on the right, dead. Blood scattered all along the road. Came up with the right wing just as they delivered 1st fire. " $\mathrm{H}$ " ordered to right and Regt with howitzers in road and on right, pushed on through timber in close skirmishing order and much confusion, firing as the enemy would occasionally, falling back, but resisting. Our men firing heavily and mostly at random, I think. Enemy firing a few rounds of grape and round shot I think but too high. So on through cornfield, and through stretch of timber. Indians and " $\mathrm{H}$ " well in front. ${ }^{55}$

General Blunt knew he could not elevate his artillery enough to work on the line of dismounted southern cavalrymen that blocked the summit of the mountain. Telling Bassett to dismount the 2nd Kansas, who occupied Shelby's old position on the small hill, he ordered a direct frontal assault against the Rebel stronghold. A storm of iron and lead rained down on the Yankee troopers, and they fell back after a halfhearted attempt to reach the top, but Blunt sent them once more into the breach, reinforced on the right by the 3rd Indian and on the left by the 11th Kansas. Now, for the first time since the battle began eight hours earlier, a real hand-to-hand melee broke out with the Rebels determined to hold their ground and the Federals just as determined to drive them off. Bullets and buckshot whistled through the trees as Captain Ross led Company E forward on the right: "One man had a button shot off his coat. Another was struck in the breast by a spent ball. Dan Horne, who is Sergeant Major of the regiment was struck in the forehead by a spent ball. A cannon ball struck a tree right over my head and a passing ball scorched my face." $" 56$

\footnotetext{
${ }^{55}$ Bodwell, Diary, November 28, 1862.

${ }^{56}$ Ross to Ross, November 30, 1862, Ross Correspondence.
} 
Most of the Rebel fire proved ineffective since it overshot the Union troopers advancing below. Simple excitement was partially responsible. Although many of the southerners fought on foot, others aimed their shotgun blasts from the back of nervous horses. Also, the trajectory of fire for black-powder weapons accounts for the failure of shots to connect. Muzzle velocity of Civil War small arms was quite slow, requiring careful calculations for barrel elevation to make shots travel to the desired target. Elevations that would place a shot accurately at a given distance on a level surface result in overshots against a target at the same distance on a downhill slope. This fortunate circumstance for the Union troops emboldened their rush up the hillside as the Rebels poured volley after volley against them.

Colonel MacDonald on Shelby's right counterattacked at one point during the assault and momentarily stalled the Federal's thrust to the mountaintop, but a glance to the road in the distance convinced him of the futility of further resistance. "Long lines of infantry and cavalry appeared," he wrote later in his report, "until it seemed that all Yankeedom had turned out."

Shelby had another horse shot from under him, and as the Federals steadily advanced to the top of the mountain, he finally ordered his men to remount and withdraw again, preparing to deploy them in the same manner as he had during the retreat from Newburg. As they descended the road to Morrow's house, they passed the Arkansas cavalry which Carroll had positioned along the road and ungraciously berated them for having taken no part in the hot engagement below.

Once he observed the enemy withdrawal, Blunt ordered his artillery forward again, and Stover's light guns raced ahead to make the new Union line at the top of the mountain. There the Federal advance had paused as Carroll's last serviceable howitzer opened up from the roadway ahead, supported by members of Colonel J. C. Monroe's regiment. Stover unlimbered and made short work of the enemy's resistance, splintering the carriage of the gun with one well-placed shot. Monroe's men, probably irritated at the taunting of their Missouri comrades, fiercely countercharged the Yankees to buy a few precious moments in which to save the gun. Once again they improvised a rope-sling and dragged the piece off to safety. ${ }^{58}$

${ }^{57} \mathrm{OR}$, vol. 22 , pt. 1,59 .

${ }^{58}$ Ibid., 55. 
Blunt now moved his army forward with steady caution, making sure the 3rd Indian and the 11th Kansas kept the right and left flanks cleared as he pushed ahead on the road with what remained of the 2nd and 6th Kansas Cavalry. A reporter with the Union army described the scene: "The cheering of the white man, the shrill war-whoops of the Indians, the clashing of sabres, and the incessant roar of small arms, converted this remote mountain gorge into a perfect Pandemonium." 59

Soon even the troopers of the 2 nd fell out, having straggled so much over the course of the last six miles that Colonel Bassett felt the need to stop and collect his force for control. But Blunt, encouraged by the sight of the slowmoving Rebel artillery before him and obsessed with the idea of capturing the guns, hurried on without them.

Colonel Carroll, still sputtering from the rebuke of the Missouri troops, found himself the senior officer of all the troops rushing down the road to Cove Creek and began to order their deployment. He placed Captain Stanley's company just before the intersection of the Cove Creek road, and he ordered Captains Gordon and Carroll to take positions on high ground below John Morrow's house. The instructions for all were the same: blast a volley at the pursuing Federals and immediately retire. Behind the Arkansans hurried the rest of Shelby's brigade with their bulldog nemesis pressing after them. ${ }^{60}$

The Cove Creek valley narrowed dramatically as the road and creek wound steadily southward, and the steep limestone bluffs on either side provided ample cover for anyone preparing an ambush. About two miles south of Morrow's place, the valley met a broad tributary from the west, causing a large flat area just before the bluffs narrowed again. This abrupt geographic feature appeared to the soldiers like a funnel, with the narrow continuation of the roadbed forming an obvious bottleneck. On the east side the heights could be gained relatively easily by a large dismounted force, and here is where Carroll positioned some men from Shelby's brigade for a final desperate ambuscade. He stationed a handful of Monroe's troopers across the road below the heights to allow the passage of the artillery and stall the Federal advance. On came the rear guard, urgently dragging the damaged artillery with the Yankees following right behind.

\footnotetext{
${ }^{59}$ Moore, The Rebellion Record, 185.

${ }^{60} \mathrm{OR}$, vol 22, pt. 1, 54.
} 
At this point in the battle General Blunt made his gravest tactical error. He had pressed on ahead of his main forces again, this time with just a few companies of the 6th Kansas, and became obsessed with one single objective: capturing the Rebel artillery before darkness closed the chase. He watched the guns rumble towards the gap with tantalizing slowness and saw only Monroe's horsemen beyond to screen their escape. Without waiting for any more reinforcements to come up, Blunt requested Jewell to take his tiny command on a reckless charge forward to capture the pieces. ${ }^{61}$

Jewell quickly formed his men for a charge, the widening portion of the valley affording enough room for the horsemen to form a line. Had the colonel paused calmly to survey the situation ahead, he might have thought back to the previous six miles of this chase and the periodic ambushes they had just fought through, but the lure of the prize proved too great for such retrospect. With sabers and pistols drawn, the Yankee cavalry charged forward at breakneck speed. Lt. A. H. Campbell recalled drawing up close enough to one Rebel trooper to thrust the barrel of his pistol right into the man's back. Unfortunately, the hammer of Campbell's weapon snapped down on an empty chamber, and he had to draw his saber to continue the fight. ${ }^{62}$ In the excitement of the chase, Dr. M. A. Campdoras, assistant surgeon of the 2nd Indian, who had been with Blunt in the advance, found himself swept up in the rush by his overly excited horse and galloped along with the troopers passing below the Rebels concealed on the high ground to the left of the road. Suddenly, Shelby's men rose in mass and poured a deadly volley right into the flank of the 6th Kansas, miraculously missing Campdoras but knocking Jewell out of his saddle and sending a bullet through Campbell's horse: "I turned, you know, to get back a way as quick as I could, and my horse hadn't made more than one jump before the volley came. Of course she went right down. I didn't breathe anything but splinters and dust for more than a minute I think." ${ }^{63}$ At least three officers died in the volley, and a dozen or more of the Yankee troopers collapsed into a huge, confused heap. ${ }^{64}$ At that moment Monroe's men made the countercharge and whirled among the survivors with sabers and shotguns. Campdoras managed to grab the gun of one Rebel who closed in on him but

${ }^{61}$ Ibid., 45.

${ }^{62}$ A. H. Campbell, interview, January 15, 1908. Kansas State Historical Society.

${ }^{63} \mathrm{Ibid}$.

${ }^{64}$ Wiley Britton, The Union Indian Brigade in the Civil War (Kansas City, MO: Franklin Hudson Publishing, 1922), 116. 
then received a blow to the back of his head which knocked him to the ground. His horse galloped away in the confusion, and he crawled to safety near a stone fence which marked the eastern boundary of the tributary valley on the west side of the road. His coat riddled with buckshot holes, Capdoras hid between two Rebel soldiers, one dead and one badly wounded, as he waited for rescue. ${ }^{65}$ An officer in Carroll's brigade, John Harrell, noted one of the prostrate figures to be a field grade officer and dismounted to examine him. A colonel as a prisoner would be a fine prize for this day's work, and even though it appeared Jewell would never recover from his wounds, Harrell, with the assistance of Maj. P. H. Wheat, moved him carefully out of harm's way by the stone fence. ${ }^{66}$

Monroe chased the survivors of the 6th Kansas almost back to Blunt's position, which, in the meantime, had been reinforced by the arrival of some soldiers from the 3rd Indian, 11 th Kansas, Stover's howitzers, and Rabb's battery. A few well-placed shells convinced the Arkansas horsemen of the wisdom of relinquishing the chase, and they turned to race back to the gap. ${ }^{67}$ Blunt, enraged that the charge had ended so disastrously, ordered the guns reloaded with double canister and approached the gap with all the forces at hand. Darkness quickly arrived to spread a veil of gloom over the scene, but the general would not give up. Telling his artillerymen to hold their fire out of compassion for his own wounded ahead, Blunt ordered the line to advance cautiously until a rider appeared from the gap bearing a white flag. The unidentified rider, sent from Marmaduke himself; requested a cease-fire to recover the wounded. Blunt reported his reaction to the request: "Consideration for the fate of Lt. Colonel Jewell and others who had fallen upon the ground which they occupied, and whom I feared they might brutally murder, induced me to respect their flag of truce, convinced though I was at the time that it was a cowardly trick, resorted to enable them to make good their retreat and save their guns. ${ }^{968}$ The truce was granted and soon the bleeding form of Jewell was brought back to Blunt's lines on a stretcher.

Edwards recalled a different ending to the fight at Cane Hill. According to him, it was Blunt that sent out a white flag to ask for the body of Jewell.

${ }^{65}$ "The Letters of Samuel James Reader, 1861-63," Kansas Historical Quarterly 9 (1940): 170n.

${ }^{66}$ Harrell, Confederate Military History, 141.

${ }^{67}$ Rieff, Cory Papers.

${ }^{68} \mathrm{OR}$, vol. 22 , pt. $1,46$. 
Edwards even related what must be a totally fictitious dialogue between Blunt and Marmaduke on some neutral ground as darkness fell:

\begin{abstract}
"Whose troops fought me today?" asked General Blunt. "Colonel Shelby's brigade," replied the generous Marmaduke, "How did they behave?" "Behave?" answered Blunt, "why, sir, they fought like devils. 250 of my best men have fallen in this day's fight, and more heroic officers than I can scarcely hope to get again. I don't understand your fighting. When I broke one line, another met me, another, another, and still another until the woods seemed filled with soldiers and the very air dark with bullets. $" 69$
\end{abstract}

Harrell, the officer who had moved Jewell out of the roadbed after the ambush, wrote his own version of the battle's conclusion in 1899: "The enemy retired voluntarily. No one ever presented for Marmaduke, or at any time had any occasion to bear, as he [Blunt] mendaciously relates, a flag of truce; for not a Confederate had been there touched, except the few who had received saber cuts before the enemy was checked."

Here is where the historian must weigh the preponderance of the evidence to establish what closed the battle of Cane Hill on November 28, 1862. ${ }^{71}$ The three 1862 reports by Carroll, Shelby, and MacDonald do not mention a flag of truce at all. Edwards, writing five years after the battle, claims to have seen one come from the Union forces, and Harrell, after a lapse of three decades, insists that no flag appeared on the field from either side. However, Union eyewitnesses are consistent: a flag of truce was seen by Sergeant Bodwell and Private Kitts of the 11th Kansas, Capt. Wiley Britton of the 6th Kansas, and

${ }^{69}$ Edwards, Shelby and His Men, 103.

${ }^{70}$ Harrell, Confederate Military History, 141.

${ }^{71}$ The battle of Cane Hill has been described in at least three articles by contemporary historians. Writing in 1961, Stephen Oates chose to ignore any mention of the truce flag in his description of the battle's end. Henry F. Hartsell examined the battle at length in 1980 and came to the conclusion, based almost entirely on evidence from the Official Records, that the flag of truce had "no significant bearing" on the conclusion of the fighting. In 1990 Allan Maul mentioned the truce flag in passing but still blamed darkness for the cessation of hostilities at Cane Hill. See Stephen B. Oates, "Cavalry Fight at Cane Hill," Arkansas Historical Quarterly, 20 (March 1961): 72; Henry L. Hartsell, "The Battle of Cane Hill, Arkansas, November 28, 1862," Journal of the West, 19 (October 1980): 60; Allan Maul, "The Battle of Cane Hill," Flashback 40 (November 1990): 34-35. 
Pvt. T. O. Adkins of Rabb's Battery. ${ }^{72}$ Added to their testimony are the accounts in the Official Records written by General Blunt and Colonel Cloud, who claimed to have received the flag once the officer approached the Union line. $^{73}$

The fact that the Confederate reports do not mention the flag of truce should not be seen as concrete evidence that they had not offered one. General Hindman, the Confederate commander, used a flag of truce just over a week later at Prairie Grove to screen the withdrawal of his mangled forces after that day's fight. In his report on the incident, Hindman claimed again that it was the Union forces who requested the humanitarian intermission from the slaughter rather than himself. In view of the evidence, the conclusion must be reached that the battle of Cane Hill was indeed terminated not by darkness, but by the white flag of Marmaduke's army.

Blunt's failure to take the enemy's guns at the end of the day can partially be blamed on the exhaustion of his troops. The distance they covered, especially given the nature of the ground, is incredible. The Federals marched about nineteen miles from start to finish, and the terrain, with its hollows, rocky ledges, and thick woods, required the men to actually cover a distance considerably greater. Perhaps even more incredible are the casualty figures. Out of a force of approximately two thousand, the Confederates reported five killed, twenty-eight wounded, and six missing. ${ }^{74}$ Maj. Robert Henry Smith reported in a letter to his wife that the southern losses stood at ten killed and fifty wounded. ${ }^{75}$ The Union army officially admitted eight killed and thirty-six wounded out of approximately five thousand men who accompanied the expedition, with Lieutenant Campbell specifically mentioned as having been taken prisoner. Even if we add a dozen or so to the butcher's bill, the casualties in this fight were very low for both sides.

As the cold November night enveloped the exhausted soldiers in the Cove Creek valley, General Blunt ordered a withdrawal of all the troops at the front and a countermarch back to Cane Hill. Picking up stragglers along the road and loading wounded into the wagons prevented the men from making much

\footnotetext{
${ }^{72}$ Kitts, "Civil War Diary”; Bodwell Diary; Britton, Union Indian Brigade; 115; Adkins to Baird, December 1862, Baird Papers.

${ }^{73} \mathrm{OR}$, vol. 22 , pt. 1, 48 .

${ }^{74}$ These figures are based on the official returns of Carrol and MacDonald's brigades. Shelby did not itemize his losses. See $O R$, vol. 2, pt. 1, 53-59.

${ }^{75}$ Smith to Smith, November 30, 1862, Smith-Mendenhall Papers.
} 
progress, and many simply dropped along the trail to find what rest they could. Captain Palmer of the 11th Kansas suffered along with his command, who sorely missed the blankets they had dropped fourteen miles back on the Rhea's Mill road. His men buried Palmer, who was delirious with illness and shivering with cold, in a pile of leaves in a desperate attempt to warm him. ${ }^{76}$ Captain Ross managed to lead his men into an impromptu camp, dismayed at only counting twenty-six men out of the sixty-seven who had started the fight that morning. ${ }^{77}$ The battle of Cane Hill was over. In a fitting epilogue to the inconclusive fight, Colonel Cloud rode out the next morning with Company $\mathrm{K}$ of the 2nd Kansas and burned the only trophy captured by Blunt's army-the disabled gun carriage Carroll had abandoned on top of the mountain,.

As we look back at the Civil War and study the clashes which highlight the conflict, we are sometimes like spectators at a courtroom drama. "Who won?" we ask, as if our ancestors's life and death struggles were closing arguments from which a judge must make a decision. The battle of Cane Hill provides no easy answer to this desire to find winners and losers. The Yankees gained the ground that cold November day and pushed the Rebels back down the road to Van Buren, depriving them of the badly needed foodstuffs which abounded in the Cane Hill area. On the other hand, the southerners got away with all the supplies they had seized during the preceding week and managed to draw Blunt south to Cane Hill, both of which were their likely objectives. The Federals displayed remarkable tenacity in their pursuit and equally abysmal judgement in their hasty attempt to capture the enemy artillery. The southerners managed to successfully duel a force nearly three times their size: yet were unable to prevent the Federals from gaining the Cove Creek road. All of these factors must be taken into account when we judge the results of the Cane Hill battle, and if, in the parlance of the courtroom, we are left with : hung jury, we probably come closest to the truth.

\footnotetext{
${ }^{76}$ Palmer, Forty Days, 220-221.

${ }^{77}$ Ross to Ross, November 30, 1862, Ross Correspondence.
} 